\title{
MEWUJUDKAN KOTA TANPA KUMUH MELALUI SISTEM KEBUN BERSAMA
}

\section{REALIZE THE CITY WITHOUT SLUMS THROUGH THE JOINT GARDEN SYSTEM}

\author{
${ }^{1)}$ Dijan Rahajuni, ${ }^{2)}$ Lilis Siti Badriah, ${ }^{3)}$ Etik Wukir Tini, ${ }^{4}$ Sri Lestari \\ ${ }^{1)}$ Program Studi Ekonomi Pembangunan, ${ }^{2}$ Program Studi Ekonomi Pembangunan, \\ ${ }^{3)}$ Program Studi Agro Tehnologi, ${ }^{4}$ Program Studi Manajemen \\ Univesitas Jenderal Soedirman \\ Jl. HR. Bunyamin No. 708 Purwokerto \\ Email: dijan.rahajuni11@gmail.com
}

\begin{abstract}
ABSTRAK
Program Kotaku (Kota Tanpa Kumuh) dilaksanakan berdasarkan Peraturan Presiden Nomor 2 Tahun 2015 tentang Rencana Pembangunan Jangka Menengah Nasional Tahun 2015-2019. Salah satu tujuan program Kotaku tercapainya kondisi 0 persen permukiman tanpa kumuh. Kelurahan Kedungwuluh Kecamatan Purwokerto Barat Kabupaten Banyumas termasuk dalam kategori kumuh ringan dengan luas wilayah 1,26 persen dari seluruh luas wilayah. Pemukiman kumuh pada umumnya identik dengan kemiskinan dan ketidakpedulian masyarakat terhadap lingkungan. Tujuan pengabdian sebagai penerapan hasil penelitian mengenai Model Pengelolaan Kelompok Swadaya Masyarakat Ekonomi Pada Program Pemberdayaan Masyarakat Kota Tanpa Kumuh. Mitra kegiatan adalah masyarakat di wilayah $R T 2 R W$ 2; RT6 RW 7 dan $R T 5 R W 8$ Kelurahan Kedungwuluh. Pelaksanaan pengabdian dilakukan melalui kegiatan sosialisasi Sistem Kebun Bersama, pemanfaatan lahan dan pemberdayaan masyarakat. Membandingkan hasil pre-test dan post- test pada Sistem Kebun Bersama dapat diketahui pemahaman masyarakat meningkat 75 persen dari semula hanya 10 persen; masyarakat secara keseluruhan memahami pemanfaatan lahan namun pelaksanaannya terkendala oleh keterbatasan waktu (65,83 persen), pengetahuan (12,67 persen), kemalasan (12,67 persen) dan biaya (5,02 persen). Hasil pemberdayaan masyarakat berupa peningkatan pendapatan dan kemandirian keuangan kelompok, jumlah kas kelompok dari hasil Sistem Kebun Bersama mulai April sampai dengan bulan September 2019 ratarata bertambah Rp513.333,00. Selain itu berdampak pula pada peningkatan kegiatan anggota kelompok karena adanya sistem piket kebun, peningkatan kepedulian terhadap lingkungan dan kerukunan antar warga, mendidik generasi muda cinta lingkungan serta mendukung pembangunan berkelanjutan.
\end{abstract}

Kata kunci: Kotaku; Pemberdayaan Masyarakat; Kelompok Swadaya Masyarakat; Sistem Kebun Bersama

\begin{abstract}
The Kotaku (Kota tanpa Kumuh / City without Slums) Program is implemented based on Presidential Regulation Number 2 of 2015 concerning the 2015-2019 National Medium-Term Development Plan (Rencana Pembangunan Jangka Menengah Nasional). One of the goals of the Kotaku program is to achieve the condition of 0 percent residence without slums. Kedungwuluh Village, West Purwokerto Sub-district, Banyumas Regency is included in the category of mild slum, with 1.26 percent slums of the total area. Slums are generally identical with poverty and community indifference toward the environment. This service aim to apply the research results on the Management Model of Community Self-help Group (Kelompok Swadaya Masyarakat/KSM) Economy in the Kotaku Community Empowerment Program. Activity partners consist of communities in the RT 2 RW 2, RT 6 RW 7 and RT 5 RW 8 neighborhood area of Kedungwuluh Village. The service is carried out through socialization of the Joint Plantation System (Sistem Kebun Bersama), land use, and community empowerment. The results of the pre-test and post-test of the community understanding on the Joint Plantation System increased to 75 percent from 10 percent in initial; on the land use theme, overall, the community understands but its implementation is constrained by time (65.83 percent), knowledge (12.67 percent), laziness (12.67 percent) and costs (5.02 percent). The results of community empowerment manifested in the form of increased income and financial independency of the group, the total group cash from the revenue of the Joint Plantation System from April to September 2019 increased by an average of Rp513.333. Furthermore, it has an impact on increasing the activities of group members because of the plantation shift system, increasing environmental awareness and harmony among residents, educating the young to love the environment, and supporting sustainable development.
\end{abstract}




\section{PENDAHULUAN}

Kota Tanpa Kumuh (Kotaku) merupakan suatu program pemerintah yang dikoordinir oleh Direktorat Jenderal Cipta Karya untuk menangani pengurangan perluasan permukiman kumuh perkotaan secara inovatif, menyeluruh, dan tepat sasaran. Program ini dilaksanakan berdasarkan Peraturan Presiden Nomor 2 Tahun 2015 tentang Rencana Pembangunan Jangka Menengah Nasional Tahun 2015-2019 yang mengamanatkan pembangunan dan pengembangan kawasan perkotaan melalui penanganan kualitas lingkungan permukiman, yaitu peningkatan kualitas permukiman kumuh, pencegahan tumbuh kembangnya permukiman kumuh baru, dan penghidupan yang berkelanjutan (Direktorat Jenderal Cipta Karya, 2016).

Tujuan dari program Kotaku adalah tercapainya kondisi 100-0-100 pada suatu kawasan, artinya pada tahun 2019 tercapai kondisi 100 persen akses universal air minum, 0 persen permukiman tanpa kumuh, dan 100 persen akses sanitasi layak. Di Indonesia pada tahun 2016 terdapat kawasan permukiman kumuh seluas $35.291 \mathrm{Ha}$, yang tersebar pada 34 Propinsi, 271 kabupaten/kota, 11.067 desa/kelurahan. Kekumuhan pada umumnya adalah identik dengan kondisi kemiskinan dan kekurangberdayaan masyarakat yang menghuni kawasan tersebut. Kekumuhan terjadi tidak hanya disebabkan karena pertambahan jumlah penduduk dan keterbatasan lahan untuk penyediaan berbagai kebutuhan, tetapi juga dikarenakan adanya kemiskinan dan ketidakpedulian masyarakat terhadap penataan dan pemanfaatan lingkungan. Menurut Azwar (1996) dalam (Susilo, Suherna, \& Juari, 2018) kekumuhan terjadi karena adanya penurunan dan kerusakan lingkungan hidup, yang disebabkan karena adanya gangguan dari lingkungan alam dan gangguan dari perilaku manusia dalam kehidupan sehari-harinya. Untuk dapat mengurangi kekumuhan yang terjadi tidak bisa hanya mengandalkan pada program dan kucuran dana dari pemerintah saja, tetapi harus melibatkan segenap unsur masyarakat penerima program.

Pemberdayaan masyarakat merupakan pelibatan masyarakat untuk meningkatkan kepedulian dan pengelolaan terhadap lingkungan, dalam hal ini terhadap lahan yang terbengkalai atau menganggur. Hal ini karena pada umumnya lahan yang terbengkalai dan menganggur merupakan salah satu sumber kekumuhan. Pada lahan ini biasanya ditumbuhi tanaman liar yang tidak teratur dan adanya kebiasaan sebagian masyarakat untuk memanfaatkannya sebagai tempat pembuangan sampah secara liar.

Pemberdayaan masyarakat merupakan suatu proses untuk meningkatkan keberdayaan masyarakat dalam berbagai aspek kehidupan, baik aspek ekonomi maupun sosial. Sumadyo (2001) dalam (Mardikanto \& Soebianto, 2013) menyatakan dalam pemberdayaan harus dilakukan kegiatan tri bina pemberdayaan, yaitu bina manusia, bina usaha, dan bina lingkungan. Program pemberdayaan akan semakin efektif apabila dalam tri bina disertai pula dengan adanya bina kelembagaan.

Pengabdian masyarakat ini merupakan penerapan hasil penelitian mengenai Model Pengelolaan Kelompok Swadaya Masyarakat (KSM) Ekonomi pada Program Pemberdayaan Masyarakat Kota Tanpa Kumuh (KOTAKU) Studi Kasus di Kabupaten Banyumas (Rahajuni, Suprapto, \& Lestari, 2018). Pengabdian dilaksanakan di wilayah Kelurahan Kedungwuluh Kecamatan Purwokerto Barat Kabupaten Banyumas, yaitu di RT 2 RW 2, RT 6 RW 7 dan RT 5 RW 8. Pemilihan tempat dilakukan berdasarkan pada kekumuhan dan kepadatan penduduk. Berdasarkan Surat Keputusan Bupati Banyumas No.050/1444/ Tahun 2014 tentang Lokasi Kawasan Kumuh di Kabupaten Banyumas, Kelurahan Kedungwuluh berada dalam kategori kumuh ringan dengan tingkat kepadatan penduduk 10.462 jiwa per $\mathrm{Km}^{2}$ dan merupakan wilayah kelurahan yang terpadat penduduknya di wilayah Kecamatan Purwokerto Barat (Badan Pusat Statistik, 2017). Di wilayah tersebut banyak terdapat lahan-lahan yang terbengkalai 
dan menganggur, padahal sebenarnya itu merupakan potensi yang bagus jika masyarakat mampu memanfaatkannya untuk kegiatan produktif. Oleh karena itu, tujuan pengabdian kepada masyarakat ini adalah memberdayakan masyarakat melalui pemanfaatan lahan yang menganggur. Obyek pemberdayaan masyarakat ini adalah lahan terbengkalai dan masyarakat sekitar lingkungan lahan kumuh tersebut terutama ibu-ibu rumah tangga, melalui upaya optimalisasi pemanfaatan lahan.

Pemanfaatan lahan-lahan tersebut antara lain dapat digunakan untuk aktivitas bercocok tanam yang dapat dilakukan secara berkelompok dengan sistem kebun bersama. Sistem Kebun Bersama ini dimaksudkan sebagai suatu sistem pemanfaatan lahan menganggur yang sebetulnya dapat diproduktifkan tetapi tidak dimanfaatkan oleh pemiliknya dan ataupun lahan-lahan sempit di pinggir jalan yang tidak mengganggu pengguna jalan untuk diproduktifkan secara bersama oleh kelompok masyarakat yang bertempat tinggal di sekitar wilayah lahan tersebut melalui suatu kesepakatan yang jelas.

Pelaksanaan Sistem Kebun Bersama ini diharapkan mampu mengurangi kekumuhan karena adanya peningkatan kepedulian masyarakat sekitar lahan untuk menata, membersihkan, dan memeliharan tanaman pada lahan tersebut.

Selain itu Sistem Kebun Bersama juga diharapkan mampu memberikan dampak positif secara ekonomi dan sosial bagi warga kelompok dan masyarakat sekitarnya. Secara ekonomi dampak positif yang dapat dinikmati oleh warga adalah hasil panen kebun dapat dimanfaatkan untuk memenuhi sebagian kebutuhan rumah tangga, yaitu sayur-sayuran dan bumbu-bumbuan. Hal ini berarti akan mampu menghemat pengeluaran rumah tangga, secara tidak langsung berkontribusi terhadap peningkatan pendapatan keluarga; hasil panen yang dapat dijual uangnya dimasukkan ke dalam kas kelompok sehingga dapat menambah kemandirian keuangan kelompok dan kesejahteraan anggota kelompok. Secara sosial kemasyarakatan dampak positif yang diharapkan berupa meningkatnya kerukunan kehidupan bermasyarakat, meningkatnya kerja sama antara kaum ibu, bapak dan anak-anak untuk menjaga dan mempedulikan lingkungan. Keterlibatan anak-anak dalam pemberdayaan lingkungan dapat dijadikan sarana untuk mendidik generasi muda cinta lingkungan, tanah air dan mendukung pembangunan keberlanjutan.

\section{METODE}

Penerapan Sistem Kebun Bersama dilakukan melalui beberapa tahapan kegiatan, sebagaimana terlihat dalam bagan pada Gambar 1, meliputi :

1. Penentuan wilayah sasaran berdasarkan pada ketentuan wilayah kumuh dan tingkat kepadatan penduduk;

2. Sosialisasi kepada masyarakat sasaran mengenai tujuan program Kotaku dan rencana pelaksanaan kegiatan pengabdian untuk mengurangi kekumuhan wilayah melalui Sistem Kebun Bersama. Pada pelaksanaan sosialisasi ini terdapat 3 wilayah di Kelurahan Kedungwuluh yang membutuhkan dan mengajukan penanganan wilayah kumuh melalui Sistem Kebun Bersama, yaitu wilayah RW 2, RW 7 dan RW 8;

3. Sosialisasi/ penyuluhan kepada masyarakat sasaran pada masingmasing RT di RW-RW tersebut yang mengajukan, yaitu RT 2 RW 2, RT 6 RW 7 dan RT 5 RW 8.

4. Materi sosialisasi meliputi: pemahaman wilayah kumuh, optimalisasi pemanfaatan lahan, dan pembentukan organisasi kelompok Sistem Kebun Bersama.

5. Implementasi Sistem Kebun Bersama.

Pemenuhan kebutuhan lahan untuk menerapkan Sistem Kebun Bersama kelompok dilakukan oleh masyarakat sasaran. Lurah, RW, dan RT melakukan pendekatan kepada masyarakat yang mempunyai lahan menganggur dan lahan pinggir jalan untuk dapat dikelola, dimanfaatkan secara bersama dan untuk kepentingan bersama melalui penanaman berbagai jenis sayuran seperti kangkung, pokcoy, tomat, terong, selada, cesim, kol, bayam, buncis, muncang, sledri, kemangi dan bumbu-bumbuan seperti serai, jahe, kunyit, brambang. Kegiatan yang dilakukan oleh masyarakat adalah menyediakan tenaga untuk mempersiapkan 
Kebun Bersama

lahan dan media tanam, merawat dan memelihara tanaman, serta melakukan pemanenan, pendistribusian hasil panen yang tidak dijual, dan melayani pembeli pada waktu panen. Kegiatan kelompok dalam Sistem Kebun Bersama adalah mencatat setiap transaksi keuangan, seperti penjualan hasil panen kebun dan pengeluaran untuk kebutuhan kebun. Tim pengabdi melakukan kegiatan pendampingan disertai dengan transfer ilmu pengetahuan berkebun, pemberian bantuan peralatan berkebun, bibit, pupuk dan obatobatan tanaman. Tim juga membuat demplot, melakukan monitoring dan evaluasi kegiatan secara berkala setiap 2 minggu.

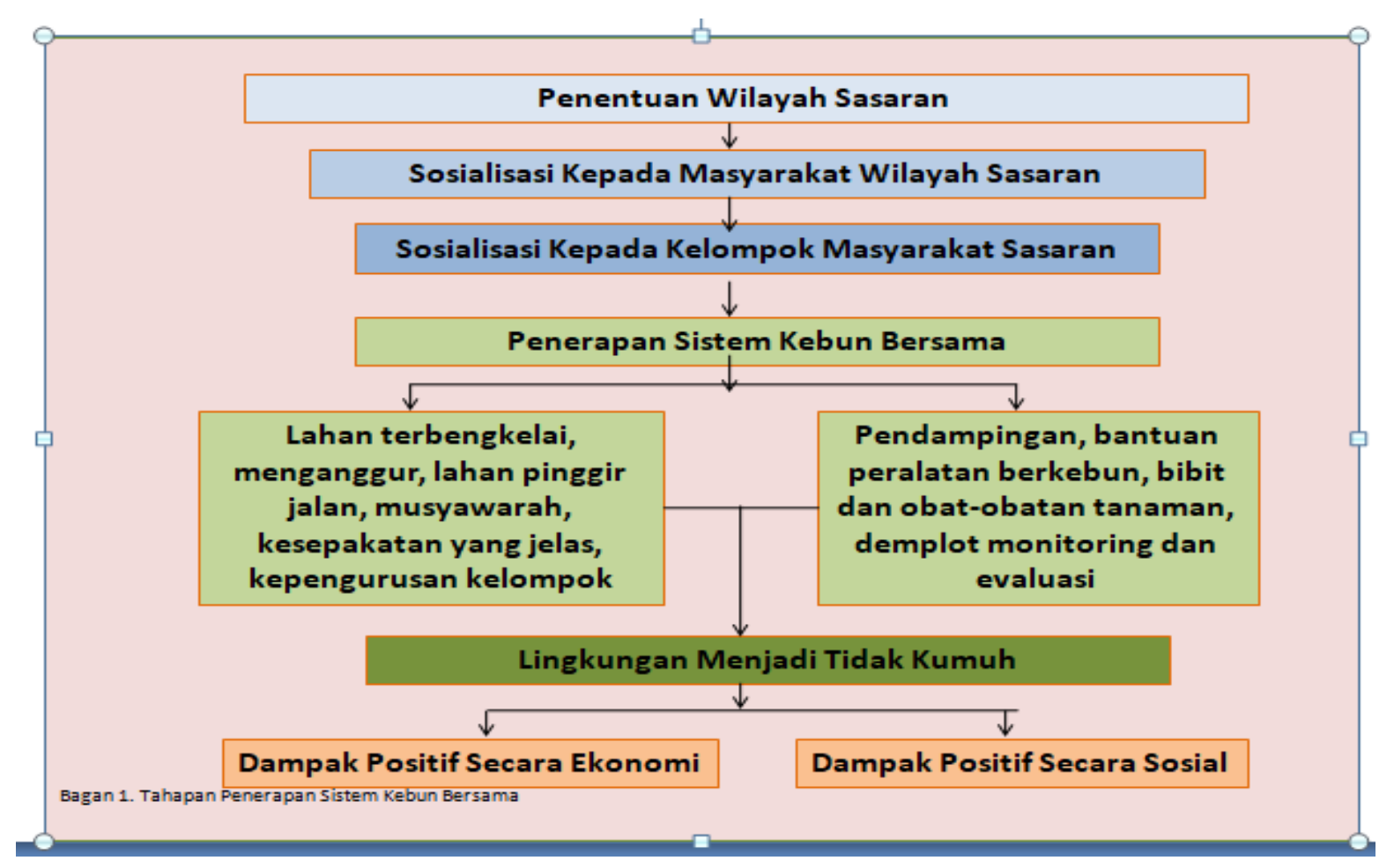

Gambar 1. Tahapan Pelaksanaan Kegiatan

\section{HASIL DAN PEMBAHASAN}

Kondisi awal tempat pelaksanaan pengabdian yang dilakukan pada RT 2 RW 2 adalah lahan pinggir jalan yang tidak tertata dan tanaman yang berserakan sehingga membuat suasana tidak nyaman untuk dilihat, pada RW 7 RT 6 yang terletak di sepanjang aliran irigasi Kranji terdapat lahan kosong di sepanjang aliran irigasi yang digunakan sebagai tempat membuang sampah dan menumpuk kayu-kayu yang tidak terpakai, dan pada RT 5 RW 8 disepanjang jalan terdapat saluran air yang terbuka dan lahan kosong milik penduduk yang tidak digunakan. Kondisi awal tempat pengabdian ini dapat terlihat pada Gambar 2. Melalui kegiatan pengabdian, dilakukan pendekatan kepada pemiliknya dengan difasilitasi oleh pihak Kelurahan, RW dan RT untuk dapat diperbolehkan memanfaatkan lahan tersebut secara bersama dan digunakan untuk kemanfaatan bersama pula.

Kekumuhan pada suatu wilayah dapat dikarenakan adanya kemunduran atau kerusakan lingkungan hidup yang diakibatkan karena fisik yaitu gangguan yang ditimbulkan oleh alam dan akibat perilaku manusia seperti kepadatan penduduk, ketidakpedulian terhadap alam dan sampah. Dampak kekumuhan terlihat dari adanya gejala-gejala yang kurang baik pada masyarakat, seperti : kondisi perumahan yang buruk, penduduk yang terlalu padat, fasilitas lingkungan yang kurang memadai, tingkah laku menyimpang, budaya kumuh dan 
kehidupan sosial yang tidak kondusif (Susilo et al., 2018). Meskipun Pemerintah telah turun tangan dalam upaya menangani kekumuhan melalui program Kotaku, partisipasi masyarakat, dan pemberdayaan masyarakat sangat diperlukan.

Untuk meningkatkan partisipasi dan pemberdayaan masyarakat dalam upaya mengurangi kekumuhan dan meningkatkan pendapatan Tim Pengabdi melakukannya melalui Sistem Kebun Bersama. Dalam upaya memberikan pemahaman kepada masyarakat mengenai kegiatan pengabdian kepada masyarakat, dilakukan sosialisasi mengenai Sistem Kebun Bersama dan mengajak masyarakat menerapkannya. Dengan membangdingkan hasil pre-test dan post-test yang dilaksanakan pada saat sosialisasi, dapat diketahui bahwa pemahaman mengenai maksud kebun bersama meningkat 75 persen dari sebelumnya yang hanya 10 persen, dan untuk penerapan Sistem Kebun Bersama ternyata belum ada satupun kelompok masyarakat yang menerapkannya. Namun demikian setelah mengetahui manfaat kebun bersama ternyata masyarakat di wilayah RT 2 RW 2, RT 6 RW 7 dan RT 7 RW 8 di mana dalam wilayah tersebut terdapat lahan yang menganggur berminat untuk menerapkannya.

Pada waktu yang sama juga dilakukan sosialisasi mengenai pemanfaatan lahan pekarangan. Berdasarkan perbandingan hasil pre-test dan post-test dapat diketahui bahwa secara keseluruhan peserta sosialisasi menyatakan memahami manfaat lahan pekarangan dan mereka sudah memanfaatkannya untuk parkir 12 orang, ditanami tanaman 45 orang, jemuran 12 orang, ternak 3 orang, jualan 1 orang dan menaruh barang 2 orang. Dalam pelaksanaan pemanfaatan lahan pekarangan ternyata waktu rata-rata yang disediakan peserta hanya 10,33 menit dalam setiap harinya. Adapun alasan mereka karena adanya kendala berupa keterbatasan waktu $(65,83$ persen), keterbatasan pengetahuan (12,67 persen), kemalasan $(12,67$ persen) dan biaya $(5,02$ persen).

Hasil pengabdian ini sejalan dengan hasil pengabdian yang dilakukan oleh Dwiratna, Widyasanti, \& Rahmah (2017) mengenai Pemanfaatan Lahan Pekarangan Dengan Menerapkan Konsep Kawasan Rumah
Pangan Lestari yang menunjukkan bahwa sebenarnya masyarakat, dalam hal ini kaum ibu, sudah menerapkan pemanfaatan lahan pekarangan, namun masih diperlukan peningkatan pengetahuan dan keterampilan. Di Desa Rawa dan Desa Lumbungsari Kabupaten Ciamis pada tahun 2017 ibu-ibu telah menerapkan pemanfaatan lahan pekarangannya, namun masih diperlukan upaya untuk mengoptimalkan pemanfaatan lahan pekarangan yaitu melalui peningkatan ketrampilan, menyiapkan media tanam, dan pembuatan pupuk tanaman berupa pupuk organik cair (Dwiratna et al., 2017).

Setelah dilakukan sosialisasi kepada kelompok masyarakat dan diperoleh kelompok masyarakat sasaran yang mau menerapkan kemudian dilakukan sosialisasi yang sama kepada kelompok masyarakat sasaran untuk lebih memperjelas pemahaman kelompok sasaran dalam menerapkan Sistem Kebun Bersama dan cara menanam tanaman jenis sayuran dan bumbu-bumbuan yang benar. Berdasarkan hasil sosialisasi ternyata secara keseluruhan kelompok masyarakat baru memahami bahwa menanam benih sayuran memerlukan perlakuan yang khusus, yaitu melalui pemberian obat penahan ketahanan terhadap hama, tidak asal menebarkan benih; demikian juga komposisi percampuran media tanam dan sistem penanamannya pada lahan yang luas dan lahan yang sempit. Dengan adanya sosialisasi pengetahuan masyarakat kelompok sasaran mengenai cara bercocok tanam meningkat, namun demikian dari 3 kelompok hanya 2 kelompok (66,66 persen) yang menerapkannya.

Untuk memotivasi masyarakat dan mengoptimalkan partisipasi masyarakat, Tim Pengabdi memberikan bantuan peralatan berkebun, media tanam, bibit dan obat-obatan pertanian, serta seperangkat buku untuk mengadministrasikan kegiatan kelompok. Dalam pelaksanaan kegiatan Sistem Kebun Bersama ternyata melalui pemberian motivasi dan stimulasi bantuan dapat meningkatkan partisipasi dan kepedulian segenap warga meliputi kaum perempuan, kaum laki-laki dan anak-anak terhadap pemanfaatan dan pengelolaan lingkungan, dalam bentuk kerja sama dan kerja bakti yang dilakukan untuk mewujudkan kebun bersama. 
Kebun Bersama

Realisasi tahapan Pelaksanaan

Kegiatan Pengabdian Sistem Kebun Bersama, terlihat pada Gambar 2, yang memperlihatkan :1). kondisi awal tempat pengabdian masyarakat; 2). sosialiasasi kegiatan pengabdian; 3). penyerahan bantuan peralatan untuk kegiatan pengabdian; dan 4). suasana pelaksanaan kegiatan lapangan pengabdian kepada masyarakat.

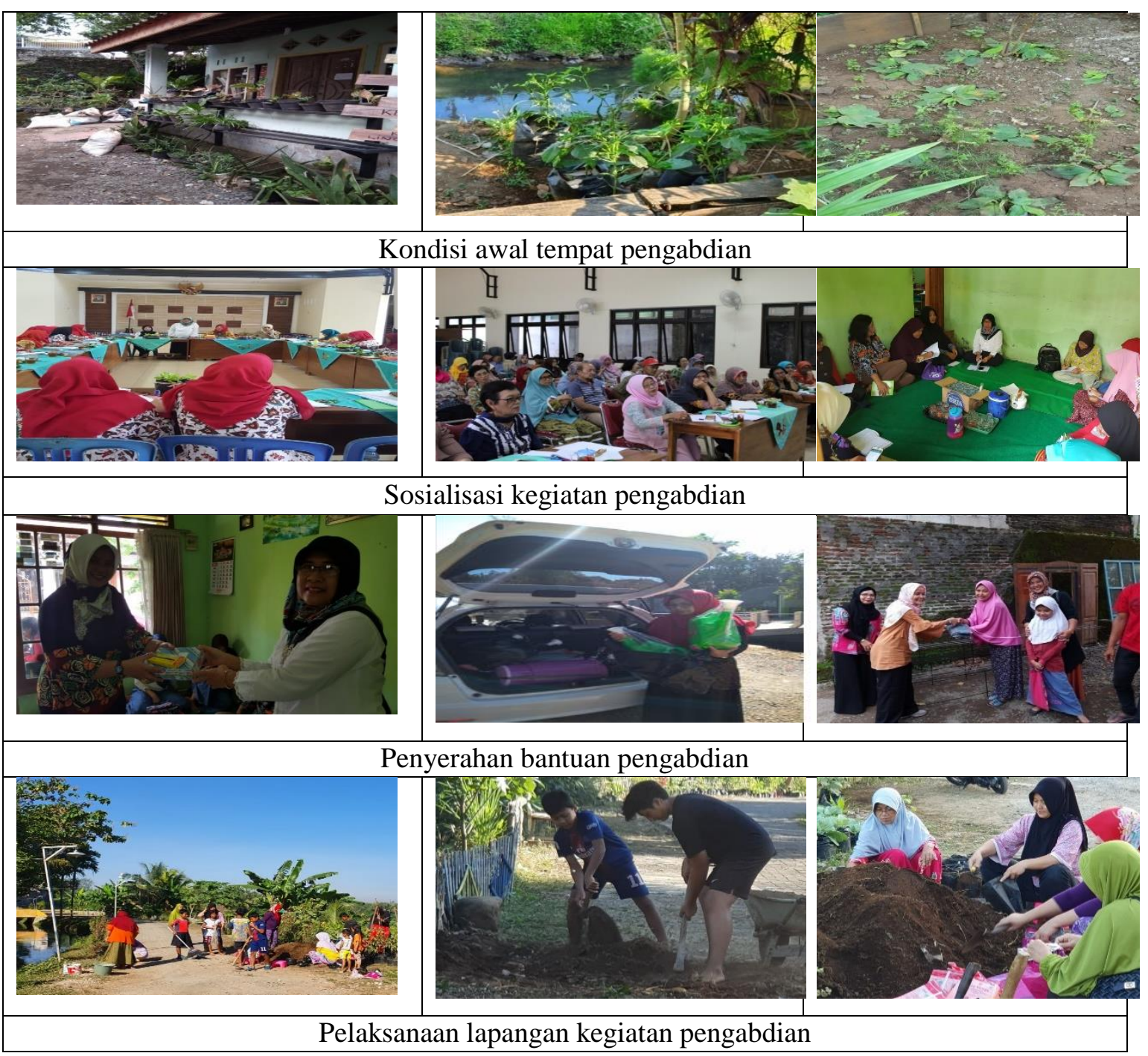

Gambar 2. Tahapan Pelaksanaan Kegiatan pengabdian Kepada Masyarakat

Selama proses Sistem Kebun Bersama, masyarakat menjadi lebih peduli terhadap kebersihan dan penataan lingkungan sehingga lingkungan menjadi terlihat tidak kumuh lagi, bahkan dapat menimbulkan suasana lingkungan yang segar dan asri. Hasil Sistem Kebun Bersama dapat terlihat pada Gambar 3. Berdasarkan kondisi ini tim Penggerak Pemberdayaan Kesejahteraan Keluarga (PKK) Kabupaten Banyumas memberikan penilaian tertinggi kedua dalam lomba pemanfaatan tanah pekarangan dan Hatinya PKK Tingkat Kabupaten Banyumas Tahun 2019.

Sistem pemeliharaan kebun bersama seperti membersihkan kebun dan menyirami tanaman dilakukan secara bergilir melalui sistem piket, sedangkan untuk tambal sulam tanaman dan pemupukan dilakukan secara bersama melalui kerja bakti yang terjadwal. Hal ini merupakan dampak positif yaitu adanya kerja sama dan kegotongroyongan, kerukunan, pelibatan anak-anak dalam membantu kerja 
bakti dan pemeliharaan tanaman sehingga secara tidak langsung hal ini merupakan sarana mendidik generasi muda untuk cinta lingkungan dan tanah air serta mendukung pembangunan berkelanjutan.

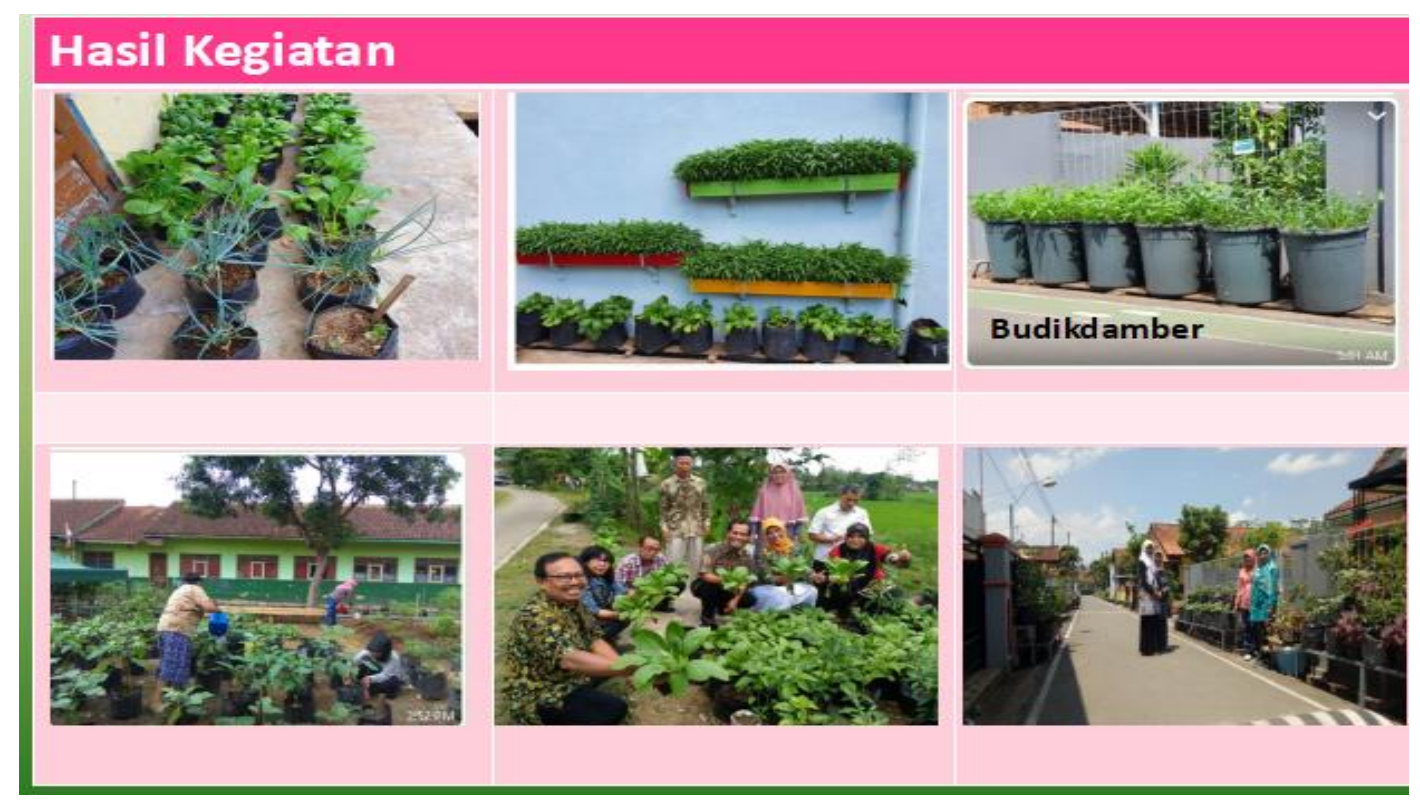

Gambar 3. Hasil Sistem Kebun Bersama

Pada sistem pemanenan hasil kebun bersama dilakukan secara bersama dengan cara menginformasikan kepada warga bahwa pada waktu yang telah ditentukan sesuai dengan kondisi tanaman akan dilakukan pemanenan. Hasil panen pada kebun-kebun bersama di peruntukan sesuai dengan kesepakatan warga. Beberapa kesepakatan hasil panen yang pernah dilakukan oleh warga adalah : hasil dibagikan kepada warga kelompok, hasil dibagikan kepada warga RT/RW sendiri dan warga tetangga, hasil dijual dan dibeli oleh warga sendiri melalui sistem lelang. Jika waktu panennya bersamaan dengan waktu pertemuan kegiatan PKK Tingkat Kelurahan maka hasil panennya dibawa ke Kelurahan dan dijual kepada anggota PKK yang ikut pertemuan melalui sistem lelang. Uang hasil penjualan panen kebun bersama dimasukkan ke dalam kas kelompok untuk membiayai berbagai kegiatan kelompok yang telah direncanakan bersama. Jumlah kas kelompok Sistem Kebun Bersama di RT 2 RW 2 sampai dengan bulan September 2019 berjumlah Rp240.000,00; RT 6 RW 7 berjumlah Rp750.000,00 dan RT 5 RW 8 berjumlah Rp550.000,00.
Hasil kegiatan ini sejalan dengan kegiatan pengabdian sebelumnya yang dilakukan oleh Saidi \& Suharyo (2016) pada model Kawasan Rumah Pangan Lestari (KRPL) di Desa Mandala Jaya Provinsi Jambi. Bedanya hanya pada pemilikan lahan di mana pada Sistem Kebun Bersama dilaksanakan pada lahan yang menganggur dan terbengkalai. Ashari, Saptana, \& Purwatini (2012) menyatakan bahwa pemanfaatan lahan pekarangan berpotensi untuk menyediakan bahan pangan dan peningkatan pendapatan keluarga, namun dalam pelaksanaannya masih bersifat subsisten, kurang ketersediaan teknologi budi daya yang spesifik, dan pendampingan tenaga penyuluh lapangan yang kurang memadai.

Dampak positif lain yang muncul pada saat panen hasil adalah adanya penghematan pengeluaran rumah tangga warga. Dengan kata lain, kebun bersama mampu berkontribusi terhadap pendapatan terutama pendapatan yang semula dialokasikan untuk membeli sayursayuran, meningkatkan kerja sama, dan kerukunan antar warga sendiri dan warga tetangga, meningkatkan penerimaan kas kelompok dan kemandirian keuangan kelompok. 
Disamping itu, sisi positif lainnya yaitu munculnya kreativitas warga dalam berkebun bersama yaitu dengan pemanfaatkan bagian atas saluran air yang tidak tertutup dan membahayakan keselamatan anak-anak warga yang bermain di jalan, menjadi ditutup dengan papan dan di atas papan dimanfaatkan untuk meletakan polybag yang ditanami tanaman sayuran. Selain itu memunculkan pula kreativitas warga melakukan budi daya ikan dalam ember (budikdamber), sehingga meskipun tidak punya lahan tetapi dapat memelihara ikan. Manfaat lain dari adanya budikdamber, yaitu warga dapat menanam sayuran kangkung air bersamaan dengan budi daya ikannya. Kreativitas ini menimbulkan dampak positif yaitu menambah keasrian lingkungan, menambah hasil panen sayuran, dan sebagai alternatif tempat bertelurnya nyamuk, namun demikian karena di dalam ember terdapat ikan maka jentik-jentik nyamuk akan menjadi makanan bagi ikan.

Faktor pendorong keberhasilan pengabdian kepada masyarakat ini adalah adanya keinginan warga masyarakat agar lingkungannya tidak kumuh, dan ini sejalan dengan kegiatan program yang dirancang oleh Tim Pengabdi serta adanya dukungan yang konsisten dari bapak Lurah Kelurahan Kedungwuluh dan juga dari Tim Penggerak PKK Kelurahan Kedungwuluh Kecamatan Purwokerto Barat kabupaten Banyumas.

Kendala yang muncul selama pelaksanaan kegiatan pengabdian adalah adanya warga yang bersikap acuh dan kendala alam berupa musim kemarau. Namun berkat motivasi yang kuat dari warga, Lurah dan Tim Penggerak PKK kendala tersebut dapat diatasi. Tim Pengabdi memberikan saran pada kelompok, yaitu untuk warga yang tidak mau bergabung dibiarkan saja sebagaimana biasanya, dan jika kebun bersama panen warga yang bersikap acuh diberi kesempatan untuk ikut merasakan hasil panen. Melalui cara demikian ternyata justru menjadikan "virus" bagi warga untuk ikut mendukung kegiatan kebun bersama. Untuk mengatasi kebutuhan air di musim kemarau ternyata dengan semangat kebersamaan agar hasil kebun bersama yang telah dicapai dan manfaat yang telah dirasakan warga secara berkelanjutan, ada warga yang dengan suka rela memberikan bantuan pompa air dan kebutuhan listriknya.

\section{SIMPULAN}

Pengabdian kepada masyarakat berdampak positif pada masyarakat, berupa : 1). Untuk Sistem Kebun Bersama, adanya peningkatan pemahaman mengenai Sistem Kebun Bersama, 85 persen masyarakat memahami dan mau menerapkannya; 2). Mengenai pemanfaatan pekarangan, secara keseluruhan masyarakat memahami manfaat lahan pekarangan namun dalam pelaksanaannya terkendala oleh waktu $(65,83$ persen), pengetahuan (12,67 persen), kemalasan $(12,67$ persen) dan biaya $(5,02$ persen); 3). Rata-rata curahan waktu untuk pekarangan rata-rata hanya 10,33 menit dan cara bertanam pun hanya asal tanam. Melalui sosialisasi secara menyeluruh, pengetahuan masyarakat mengenai cara bercocok tanam meningkat, namun demikian hanya 66,66 persen yang mau menerapkannya. Secara ekonomi hasil kegiatan Kebun Bersama mampu meningkatkan pendapatan kelompok masyarakat. Selama April sampai dengan September pemasukan kas kelompok rata-rata Rp513,33.

Dampak positif lainnyanya yaitu masyarakat menjadi lebih peduli terhadap pemanfaatan lahan pekarangannya, adanya peningkatan kerja sama antar warga dan kerukunan berkehidupan hal ini terlihat adanya peningkatan kerja bakti yang dilakukan melalui sistem piket kebun, mendidik generasi muda untuk cinta lingkungan dan tanah air hal ini terlihat pada keikutsertaan anak-anak dalam berkebun.

Kegiatan pengabdian dapat berhasil manakala adanya dukungan dari masyarakat dan pemerintah lokal. Masyarakat dan pemerintah lokal akan mendukung kegiatan pengabdian yang dilakukan oleh Tim Pengabdi ketika mereka merasakan memang membutuhkan dan kegiatan-kegiatan yang dilakukan Tim Pengabdi memberikan manfaat serta dampak yang positif bagi mereka. Oleh karena itu, dalam merencanakan kegiatan pengabdian harus sesuai dengan kondisi kebutuhan masyarakat dan harus disosialisasikan secara jelas dan terinci. Untuk menjaga keberlanjutan penerapan kegiatan hasil pengabdian pada masyarakat, Tim Pengabdi perlu terus menjaga komunikasi, pendampingan, dan monitoring secara berkala. 


\section{DAFTAR PUSTAKA}

Ashari, Saptana, \& Purwatini. (2012). Potensi dan Prospek Pemanfaatan Lahan Pekarangan Untuk Mendukung Ketahanan Pangan. Forum Penelitian Agro Ekonomi, 30 (1), 13-30.

Badan Pusat Statistik. (2017). Kacamatan Purwokerto Barat Dalam Angka. Banyumas.

Direktorat Jenderal Cipta Karya. (2016). Surat Edaran Nomor: 40/SE/DC/2016 TENTANG PEDOMAN UMUM PROGRAM KOTA TANPA KUMUH. Jakarta.

Dwiratna, N. P. S., Widyasanti, A., \& Rahmah, D. M. (2017). Pemanfaatan Lahan Pekarangan Dengan Menerapkan Konsep KAWASAN Rumah Pangan Lestari. Abdimas Unnes, 21(1), 75-80.

Mardikanto, T., \& Soebianto, P. (2013). Pemberdayaan Masyarakat Dalam
Perspektif Kebijakan Publik. Bandung: Alfabeta.

Rahajuni, D., Suprapto, \& Lestari, S. (2018). Model Pengelolaan Kelompok Keswadayaan Masyarakat (KSM) Ekonomi Pada Program Pemberdayaan Masyarakat Kota Tanpa Kumuh (Kotaku) Studi Kasus Di Kabupaten Banyumas. Purwokerto.

Saidi, B., \& Suharyo. (2016). Optimalisasi Pemanfaatan Lahan Pekarangan Dengan Model Kawasan Rumah Pangan Lestari (KRPL) Di Kabupaten Tanjung Jabung Barat Provinsi Jambi. Jurnal Penelitian Universitas Jambi Srei Sain, 18(2), 31-38.

Susilo, G., Suherna, \& Juari. (2018). Pendampingan Pemberdayaan Masyarakat Program 100-0-100 di Kelurahan Manggar. Jurnal Pengabdian Kepada Masyarakat Universitas Balikpapan, 1(2), 227-236. 